\title{
Articles
}

\section{Ukrainian policies in the Black Sea littoral: history, current trends and perspectives}

Ostap Kushnir $\nabla$ iD

Pages 163-179 | Published online: 10 Aug 2016

G6 Download citation $\quad \boldsymbol{D}$ http://dx.doi.org/10.1080/14782804.2016.1219845

(D) Check for updates

\section{E Full Article}

\section{Abstract}

The article focuses on the Ukrainian geopolitical presence in the Black Sea littoral tracing its development since the beginning of the twentieth century. An attempt is made to predict the future regional policies of Ukraine taking into account ongoing irreversible processes: the recent Ukrainian democratic revolution, early presidential elections of 2014, growing Russian confrontation with the Western states, ongoing insurgency in the Eastern Ukraine, promising cooperation with Turkey and others. Apart from this, the outlines are drafted for Ukraine to fully benefit from the available political and economic options in the current discourse. Finally, the article includes arguments for the EU, U.S. and NATO to revise their modus operandi in the Black Sea littoral and make a stake on Ukraine as on the champion of the liberal values and democracy. 